\title{
KOMERSIALISASI DAN TRANSFORMASI ORIENTASI PRAKTEK KEAGAMAAN : ANALISA E-PAYMENT "PAYTREN" USTADZ YUSUF MANSUR
}

\author{
Tri Djoko Pariworo
}

U niversitas Indonesia

\begin{abstract}
A bstract
Contemporary Islamic studies show a lot of the development of the method of da'wah in the digital age society, the more varied and the forms. The method of da'wah in the style of conventional lectures is no longer the only method used by religious teachers. Technological advances through applications as religious products can be the medium used in preaching one of them, namely Ustadz Yusuf Mansur through the Paytren application. This study argues that the commercialization of religion with the method of buying and selling spiritual products is a form of representation of the commodification of religion which results in the transformation of forms of religious practice in digital era society which is reflected in the Paytren paid user application community initiated by Ustadz Yusuf Mansur. This causes religious understanding as well as religious practices to take place through the consumption of commercial religious products. This research was conducted using a qualitative approach by conducting observations and interviews with users of the "Paytren" epayment application initiated by Ustadz Yusuf Mansur.
\end{abstract}

Keywords : Commercialization of Religion, Paytren, Orientation of religious practices

\begin{abstract}
A bstrak
Kajian Islam kontemporer banyak menunjukkan perkembangan metode dakwah pada masyarakat era digital semakin variatif ragam dan bentuknya. M etode dakwah dengan gaya ceramah konvensional tidak lagi menjadi satusatunya metode yang dilakukan oleh kalangan ustadz. Kemajuan teknologi melalui aplikasi sebagai produk keagamaan bisa menjadi medium yang digunakan dalam berdakwah salah satunya yaitu ustadz Yusuf Mansur melalui aplikasi Paytren. Penelitian ini berargumen bahwa komersialisasi agama dengan metode jual beli produk-produk spiritual merupakan wujud representasi dari komodifikasi agama yang menghasilkan transformasi bentuk praktek keagamaan di masyarakat era digital yang tercermin dalam komunitas pengguna aplikasi berbayar Paytren yang digagas oleh Ustadz Yusuf Mansur.
\end{abstract}


$\mathrm{Hal}$ ini menyebabkan pemahaman agama sekaligus praktek agama berlangsung melalui konsumsi produk keagamaan yang komersial. Penelitian ini dilakukan dengan menggunakan pendekatan kualitatif dengan cara melakukan kajian literature, observasi dan wawancara terhadap para pengguna aplikasi e-payment "Paytren" yang digagas oleh ustadz Yusuf Mansur.

Kata kunci : Komersialisasi Agama, Paytren, Orientasi praktek keagamaan

\section{Perkembangan Metode Penyampaian Dakwah}

Berkembangnya metode penyampaian dakwah dalam ajaran agama Islam di Indonesia salah satunya ditunjukkan dengan penyampaian dakwah yang disiarkan oleh beberapa media salah satunya televisi. Dakwah yang disampaikan oleh agen dakwah seperti kyai, ulama, ustadz, atau sebutan pemuka agama Islam lainnya tidak hanya didengarkan oleh para jamaah ${ }^{1}$ yang berada dalam satu ruangan atau satu tempat dengan agen dakwah tersebut melainkan dengan disiarkannya dakwah tersebut oleh televisi membuat proses penyampaian dakwah juga dapat didengarkan oleh jamaah lainnya yang tidak berada dalam tempat yang sama dengan agen dakwah tersebut melainkan menontonnya melalui layar televisi dan media lainnya seperti online.

Dengan kepopuleran yang didapat melalui dakwah melalui stasiun televisi tersebut, beberapa ustadz dengan gaya ceramah baru ini mendapatkan ciri khas atau karakteristik yang menjadi gelar yang disematkan kepadanya seperti ustadz Yusuf Mansur yang dikenal dengan layanan paytren dengan tagline "sedekah" yang sangat khas. Gaya berceramah baru inilah yang kemudian menjadi daya tarik khususnya bagi kalangan kelas menengah dan anak muda yang membedakan dengan penceramah terkemuka sebelumnya yang secara ilmu agama lebih mapan. Gaya berceramah baru seperti yang dilakukan ustadz Yusuf Mansur melalui aplikasi paytren-nya ini yang disebutnya mudah dan praktiks serta jauh dari kesan politis menjadi daya tarik utama masyarakat saat ini.

Dengan kepopuleran yang didapat oleh para ustadz tersebut melalui gaya dakwah yang unik dan didukung dengan media baik itu media televisi ataupun media online sebagai salah satu sarana saluran dakwah

1 Jamaah lazimnya merupakan sebutan untuk para peserta yang hadir dalam suatu majelis taklim atau perkumpulan agama dalam jumlah yang banyak sepertinya hal ketika kita menyebut solat berjamaah yang terdiri dari banyak orang dalam satu tempat 
tersebut membuat kehidupan mereka kini menjadi konsumsi publik. Kemunculan ustadz selebritis baik dalam acara-acara yang bersifat off-air atau on-air dengan ciri khas dan gaya dakwah yang melekat kepadanya menjadi lebih menonjol dibandingkan dengan isi atau muatan ceramah yang disampaikannya. Sebagaimana selebriti pada umumnya, ustadz selebritis tidak hanya dilihat ketika dirinya tampil menyampaikan dakwahnya melainkan diluar hal tersebut seperti kebiasaan dirumah atau aktivitas sehari-harinya menjadi konsumsi publik dalam "balutan" kamera televisi pada umumnya atau dunia infotainment pada khususnya. $\mathrm{Hal}$ ini sepaham dengan definisi dari "celebrity" yang dikemukakan oleh beberapa ahli yang menyebutkan bahwa "celebrity meaning is a person who is easily recognized by many people from many backgrounds and often appears or becomes news in the mass media". 2

Ketika seseorang menjadi selebritis dan menjadi pusat perhatian akan banyak orang yang melihat eksistensi dirinya dan apa yang dilakukan olehnya akan menjadi trendsetter bagi banyak orang. Dari yang tidak mengenal menjadi kenal, dari yang kenal menjadi tahu, dari yang tahu menjadi lebih tahu, dan dari yang lebih tahu bisa mengacu pada fanatik yang kemudian apapun yang dihasilkan dan dilakukan oleh seleb tersebut akan diikuti bahkan diimitasi oleh para pengikutnya.

\section{Kajian Mengenai Komersialisasi Dakwah}

Melihat perkembangan kajian mengenai fenomena ustadz selebritis ini sebenarnya cukup banyak sudah pernah dilakukan oleh beberapa penelitian sebelumnya. Kajian mengenai Islam kontemporer di Indonesia sebagian besar banyak dikaitkan dengan sudut pandang naratif melalui aspek historis dan sudut pandang komodifikasi agama. Dalam kajian naratif dijelaskan bahwa Islam memiliki nilai-nilai yang disampaikan secara ringan, praktis, dan aplikatif. Islam mengajarkan semangat memotivasi diri untuk menjadi pribadi yang semakin baik yang dicontohkan dalam kehidupan sehari-hari seorang muslim. ${ }^{3} \mathrm{Hal}$ ini banyak dilakukan dalam sudut pandang historis melalui penelusuran berbagai sejarah perkembangan Islam di beberapa dunia termasuk di Indonesia. Dalam beberapa kajian juga disebutkan nama-nama pendakwah atau ustadz yang berkembang menjadi populer seiring dengan sarana dakwah yang digunakan dalam menyiarkan kegiatan dakwahnya.

2 Coutas, Penelope. 2008. Fame, Fortune, Fantasy : Indonesia Idol and The N ew Celebrity dalam Ariel Heriyanto (ed.), Popular Culture in Indonesia; Fluid Identities in Post-A uthoritarian Politics. New York: Routledge

3 Islam disampaikan salah satunya melalui sarana media digital dengan cara-cara yang dekat dengan kehidupan sehari-hari. 
Kajian mengenai komersialisasi dakwah agama dengan beragam kasus dan pendekatan yang digunakan, mayoritas ketika membahas kajian mengenai Islam menggunakan tema tentang komersialisasi sebagai alat analisanya menyebutkan bahwa globalisasi dan modernisasi mengakibatkan tergoyahnya kemantapan identitas keagamaan dan pencarian akan kepastian moral di tengah kaum Muslim khusunya kelas menengah. Beberapa kajian mengenai komersialisasi dakwah ini menjadi daya tarik tersendiri ketika membahas tema yang berkaitan dengan tema agama (dalam hal ini Islam). Komersialisasi disini erat kaitannya dengan masalah modernisasi, global isasi, konsumerisme, dan industri media yang saat ini berkembang dengan pesat. Kajian-kajian tersebut menitikberatkan pada kajian mengenai komersialisasi dakwah agama yang berkaitan dengan perubahan sosio-kultural akibat adanya arus modernisasi dan implikasinya terhadap identitas individu.

Melalui penelusuran kajian-kajian sejenis khususnya berkaitan dengan komersialisasi dakwah seperti yang disebutkan diatas, peneliti ingin melihat bagaimana bentuk perubahan yang terjadi dalam orientasi praktek keagamaan yang ada dalam masyarakat kita saat ini. Dengan kata lain penelitian ini ingin menunjukkan bahwa komodifikasi agama dalam bentuk komersialisasi produk keagamaan telah merepresentasikan bentuk praktek keagamaan di masyarakat dalam bentuk jual beli produkproduk spiritual dan ceramah gaya baru yang tercermin dalam komunitas pengajian yang difasilitasi oleh ustadz sebagai pendakwah. Metode atau strategi dakwah yang dilakukan oleh beberapa ustadz yang yang cukup populer tidak lagi hanya terpaku pada cara-cara tradisional dalam menyampaikan ajaran agama khususnya agama Islam untuk menjadi pribadi lebih baik melalui metode ceramah, namun berkembang caracara baru dalam berdakwah diantaranya dengan berbisnis atau berdagang melalui produk-produk keagamaan seperti yang dilakukan Ust. Yusuf Mansur dengan aplikasi berbayar Paytren-nya.

Komodifikasi agama dalam bentuk komersialisasi nilai-nilai dan simbol keagamaan yang melekat dalam sosok seorang ustadz telah membentuk status seorang ustadz menjadi hal yang bertentangan dimana di satu sisi mengajarkan tentang moral kehidupan dan cara menjadi pribadi yang lebih baik, namun di sisi lain mengajak orang atau pengikutnya untuk mengikuti ajarannya melalui produk-produk komersial yang "dibungkus" dengan gaya yang islami. Ciri khas dan gaya penyampaian dakwah baru yang unik dan menarik dari para ustadz tersebut yang difasilitasi dalam media baik itu televisi maupun online tidak semata "memperdagangkan" Islam tetapi juga merupakan cara memperkenalkan nilai-nilai Islam dengan cara yang baru, ringan, praktis, dan aplikatif. 
Dalam perkembangannya saat ini, kita dapat melihat beberapa halhal yang menarik dari munculnya ini dalam masyarakat dimana nilainilai keagamaan dalam bentuk berdakwah dan ritual ibadah memiliki beberapa transformasi bentuk yang tidak hanya terpaku pada hal yang berhubungan langsung dengan hal-hal yang sifatnya spiritual namun secara tidak langsung mengalami suatu bentuk kegiatan yang memiliki unsur nilai material. Dahulu masyarakat melakukan kegiatan keagamaan untuk mendapatkan keberkahan, ketenangan dalam hidup, serta meningkatkan sisi religiusitasnya dengan kegiatan yang bersifat normatif yang diajarkan agamanya masing-masing seperti dalam Islam yaitu sholat, zakat, puasa dan ibadah umroh atau haji (pergi ketanah suci) dalam agama Islam. Semua kegiatan tersebut semata-mata dilakukan untuk mendekatkan diri kepada Tuhannya.

Namun saat ini berkembang metode atau bentuk kegiatan lain yang bisa dilakukan untuk mendekatkan diri kepada Tuhannya yang diantaranya digagas oleh para ustadz Yusuf Mansur. Ustadz Yusuf Mansur dengan metode pembayaran Paytren ${ }^{4}$. Dalam aplikasi paytren terdapat gejala dimana para penggunanya menggunakan aplikasi tersebut untuk setiap kegiatan transaksinya yang dinilai sebagai bentuk ibadah dalam praktek keagamaannya. Dalam metode tersebut terkandung nilai-nilai spiritual keagamaan yang mengajarkan individu untuk mengingat dan beribadah kepada Tuhannya, namun di sisi lain secara tidak langsung terdapat nilai material dan nilai pertukaran melalui produk keagamaan yang ditawarkan oleh ustadz Yusuf Mansur dalam bentuk transaksi jual beli melalui aplikasi berbayar paytren di media online. Hal ini menunjukkan bagaimana komersialisasi ini berlangsung melalui penyesuaian real itas lokal dengan melihat konteks perkembangan masyarakat saat ini khususnya masyarakat kelas menengah atau kaum urban yang tinggal di wilayah perkotaan. ${ }^{5}$

Produk keagamaan paytren ini merupakan identitas yang melekat pada ustadz Yusuf Mansur yang digunakan dalam kegiatan berdakwahnya. Produk keagamaan melalui aplikasi berbayar paytren yang digagas oleh ustadz Yusuf Mansur tersebut memiliki nilai komersial selain nilai guna dalam penyampaian metode dakwahnya. Dalam hal ini nilai guna mengalami transformasi sebagai nilai tukar. Hal ini juga diperkuat dengan identitas dari ustadz tersebut yang memiliki tambahan gelar "selebritis" yang membuat sosoknya menjadi lebih terkenal dibandingkan dengan ustadz-ustadz Iainnya. Melalui identitas yang dikenal di masyarakat melalui beberapa media semakin mempermudah

4 Paytren merupakan metodetransaksi pembayaran pengganti al at tukar tunai (uang) dimana sistem pemasarannya dikembangkan melalui kerjasama kemitraan dengan konsep jejaring. Metode ini merupakan bentuk aplikasi teknologi yang digunakan dalam smartphone. 
"pemasaran" atau cara berdagang ustadz Yusuf Mansur tersebut dalam memasarkan produk keagamaan yang dihasilkannya untuk dikonsumsi oleh sebagian masyarakat khususnya beberapa jamaah atau pengikutnya yaitu para pengguna aplikasi paytren.

Melalui penelitian ini penulis ingin memperkaya kajian mengenai Islam kontemporer yang memfokuskan permasalahan mengenai komersialisasi dakwah melalui argumentasi bahwa komodifikasi agama dalam bentu komersialisasi agama dengan metode jual beli produkproduk keagamaan merupakan bentuk dari komodifikasi agama yang menghasilkan transformasi orientasi bentuk praktek keagamaan di masyarakat yang tercermin dalam komunitas pengajian yaitu para pengguna aplikasi paytren yang tergabung dalam "komunitas paytren" yang difasilitasi oleh ustadz Yusuf Mansur tersebut.

\section{Komodifikasi \& Komersialisasi : Wujud dan Praktek Transformasi Nilai}

Fealy (2012) menyebutkan bahwa konsumsi Islam sebagai komoditas keagamaan saat ini telah menyebar dan berkembang di Indonesia dan memiliki akibat-akibat secara ekonomi dan budaya yang bersifat kompleks secara prosesnya. Komodifikasi Islam mencerminkan peningkatan religiusitas dalam masyarakat Indonesia sekaligus membenarkan bahwa tumbuhnya konsumsi akan produk-produk Islam mendorong proses Islamisasi lebih jauh sebagai bagian dari ungkapan atas keimanan dari agama yang dianut. ${ }^{6}$ Peningkatan konsumsi keagamaan sebagai akibat dari modernisasi, urbanisasi, dan gl obalisasi dapat dilihat sejak era tahun 1970-an ketika Indonesia melalui rezim Soeharto membuka aliran dana asing dalam jumlah besar dan menekankan pembangunan pada sektor industri, sumber daya, dan pangan. Dalam hal ini Fealy menyebutkan bahwa perilaku keagamaan adalah salah satu bidang yang telah mengalami perubahan dramatis di kota-kota sebagai akibat dari modernisasi, urbanisasi, dan globalisasi tersebut merujuk hal ini kepada “kegoncangan kemantapan identitas keagamaan" yang terjadi ketika masyarakat mengalami transformasi sosial dan budaya. Sebagai bentuk akibat dari kegoncangan identitas kegamaan ini adalah mencari sumbersumber bimbingan moral yang baru dan bantuan melalui keagamaan. Proses pencarian ini banyak dilakukan dengan mengikuti perkembangan pasar karena pengguna agama mencari identitas baru dan makna yang

5 Geertz, Clifford. 1986. Islam O bserved : Religious D evel opment in M arocco and Indonesia. New Heaven and London : Yale University Press, chapter 1, "T wo Countries, Two Cultures".

6 Fealy et.al (2012) U stadz Seleb, Bisnis M oral \& Fatwa O nline : Ragam E kspresi Keislaman Indonesia Kontemporer. Depok : Komunitas Bambu. hlm. 26. 
bersifat pribadi di dunia jual-beli spiritual. Proses ini bersifat personal atau pribadi dan berpusat pada hal yang bersifat self-consume. ${ }^{7}$

Persoalan mengenai komersialisasi ini sebelumnya sedikit dibahas dalam kerangka besar komodifikasi agama. Mosco (2009) sendiri juga menyebutkan bahwa komersialisasi merupakan spesifikasi dari proses komodifikasi dalam artian yang lebih sempit yaitu proses yang secara khusus mengacu pada penciptaan sebuah bentuk hubungan atau relasi antara "penyedia" dengan "pengguna" atau penonton dengan pengiklan yang melibatkan komoditas. Dalam hal ini hubungan yang terbentuk bersifat saling menguntungkan. Hal serupa dengan Mosco mengenai definisi komersialisasi ini juga dikemukakan oleh Yuliharto (1993) yang menyebutkan bahwa komersialisasi ini merupakan suatu istilah kritis yang mengacu pada kecenderungan di dalam kapitalisme yaitu mengubah suatu hal menjadi barang dan jasa yang dijual untuk memperoleh keuntungan. ${ }^{8}$ Melalui definisi tersebut dapat dilihat bahwa komersialisasi ini merupakan transformasi nilai guna menjadi nilai tukar yang memberikan keuntungan.

Dalam ranah agama, istilah komersialisasi ini cukup sering dikaitkan khususnya dalam perkembangan masyarakat saat ini yang semakin terbuka dengan informasi-informasi yang didapat dari berbagai sumber khususnya media meliputi elektronik seperti televisi, radio, dan gadget serta media cetak seperti koran dan majalah, serta media online yang erat kaitannya dengan teknologi. Komersialisasi agama disini menjadikan agama sebagai barang komoditas atau dagangan untuk memperoleh keuntungan. Ketika barang komoditas tersebut disukai dan dibeli oleh konsumennya, maka eksistensi dari keberadaan barang tersebut akan terus dipertahankan mengikuti tuntutan pasar. Yang menarik dalam hal mengenai komersialisasi agama ini adalah bagaimana agama yang secara normatif berperan sebagai "the way of life" kini mengalami pergeseran menjadi "life style".

\section{Paytren Dalam Dakwah Ustadz Yusuf Mansur}

Ustadz Yusuf Mansur dikenal sebagai salah satu ustadz yang cukup populer di Indonesia. Perjalanan karir ustadz Yusuf Mansur, baik sebagai ustadz maupun pengusaha semakin berkembang. Seiring dengan kemajuan karirnya, ustadz Yusuf Mansur mengembangkan sebuah perusahaan yang bernama PT. Veritra Sentosa Internasional (VSI). ${ }^{9}$

7 ibid.

8 Yuliharto, Freddy 1993. G ejolak Kapitalisme. Jakarta : Golden Terayon Press. hlm. 26.

9 Diakses dari https://old.treni.co.id/w p.../Profil-Perusahaan-PT.-V eritra-Sentosa-Internasional (diakses tanggal 14 A gustus 2018). 
Pendirian perusahaan tersebut berangkat dari keprihatinan Ustadz Yusuf Mansur terhadap kondisi pada saat itu, dimana beliau melihat banyak aset negara yang beralih kepemilikan ke tangan asing, serta banyaknya toko kelontong dan tradisional yang mengalami kesulitan bersaing dengan toko retail modern yang lebih memiliki modal besar. Sehingga muncul gagasan dari Ustadz Yusuf M ansur untuk mengembangkan sebuah software penjualan pulsa dan all-payment gateway- yang umumnya hanya dimiliki oleh toko retail modern, dapat dimiliki juga oleh pemiliki toko kelontong tradisional. Dengan adanya fasilitas berupa softaware yang dapat membantu perekonomian dari toko kelontong maupun toko tradisional yang sederhana, yang dapat digunakan untuk melakukan pelayanan berupa penjualan pulsa GSM/ CDMA semua operator, tagihan internet, TV kabel, PDAM dan tiket, sehingga hal tersebut dapat meningkatkan nilai tambah bagi toko kelontong tersebut yang diharapkan dapat meningkatkan penghasilan dari pemilik toko tersebut. Ustadz Yusuf Mansur berharap produk paytren dapat dinikmati dan dijangkau oleh seluruh lapisan masyarakat untuk menjadi Pengguna ataupun Pebisnisserta dapat digunakan untuk menghasilkan peningkatan keuntungan dan menjadi

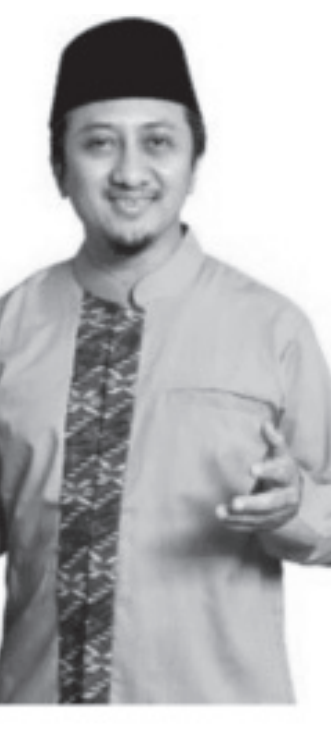
bisnis yang dijalankan secara bersama-sama dengan Konsep Berjamaah dalam mencapai kesejahteraan bersama. ${ }^{10}$

Fitur utama yang ditawarkan dalam aplikasi paytren adalah produk pembayaran yang dapat membantu masyarakat di dalam melakukan pembayaran rutin tiap bulannya, melalui pendekatan penggunaan teknologi gadget atau smartphone. Paytren merupakan aplikasi untuk kegiatan pembayaran, baik secara online maupun offline, yang dibuat oleh ustadz Yusuf Mansur. Dengan paytren maka seluruh transaksi pembayaran seperti pembelian pulsa, pembelian token listrik, pembelian tiket pesawat dan kereta api, pembayaran PDAM, pembayaran tagihan listrik, pembayaran iuran BPJS serta jenis pembayaran lainnya, dapat dilakukan dengan menggunakan telepon genggam saja.

10 Diakses dari https://www.suara.com/bisnis/2017/10/21/114357/yusuf-mansur-dari-dakwahmerambah-dunia-bisnis diakses pada 2 September 2018 (Adhitya Himawan, 2017). 
Paytren merupakan salah satu aplikasi transaksi mobile yang dapat digunakan untuk berbagai jenis pembayaran dan pembelian, dimana juga dapat memberikan berbagai manfaat dan keuntungan setiap bertransaksi bagi penggunanya. Sistem paytren ini juga dirancang dengan mengutamakan pemberian kemudahan pelayanan, keamanan dan kenyamanan untuk para penggunananya dalam melakukan transaksi secara online. Pada saat ini, paytren sudah dapat digunakan dan diaplikasikan pada seluruh smartphone baik yang berbasis Android dan iOS, dan aplikasi ini akan terus dikembangkan dan disesuaikan dengan kemajuan teknologi digital.

Sebagai salah satu perusahaan aplikasi pembayaran, paytren telah memiliki jumlah anggota yang sangat besar. Hingga bulan April 2018 saja, jumlah anggota yang tercatat kurang lebih sekitar 2 juta orang. Dalam waktu satu tahun, diperkirakan peningkatan jumlah anggota dari paytren lebih dari $65 \% .{ }^{11}$ A nggota komunitas paytren tidak hanya tersebar dari Pulau Sumatera di bagian barat Indonesia hingga ke Pulau Papua di sebelah timur Indonesia saja, akan tetapi juga menyebar hingga keluar negeri.

Pada dasaranya, anggota komunitas paytren ini merupakan para pengguna aplikasi paytren dalam setiap transaksi kehidupan mereka di berbagai kalangan dan Iapisan sosial masyarakat baik dalam kalangan atas maupun bawah. Alasan utama para pengguna aplikasi paytren ini menggunakan paytren sebagai media alat pembayaran berbagai macam transaksi dikarenakan beberapa hal yaitu: kemudahan yang diberikan dalam paytren ketika transaksi apapun dapat dilakukan dimana saja dan kapan saja dengan menggunakan aplikasi gawai; keuntungan yang didapat melalui setiap transaksi yang dilakukan sekaligus lebih murah secara biaya; da nada nilai sedekah dalam setiap transaksi yang dilakukan sehingga mereka merasa mendapatkan keberkahan melalui transaksi pembayaran ekonomi yang mereka lakukan.

Melihat bagaimana aplikasi paytren yang digagas oleh Ustadz Yusuf Mansur ini mulai berkembang dengan pesat khususnya dengan perkembangan teknologi smartphone membuat penyampaian dakwah agama menjadi lebih fleksibel dan semakin mudah dijangkau oleh berbagai kalangan masyarakat, membuat jumlah pengguna aplikasi semakin bertambah dengan jumlah nilai transaksi yang cukup besar. Hal ini juga didukung dengan semakin bertambah banyaknya jenis transaksi yang dapat dilakukan dengan aplikasi paytren ini. Aplikasi paytren ini menjadi semacam praktek keagamaan baru yang berjalan dalam industri ekonomi.

11 Diakses dari https://republika.co.id/berita/ekonomi/syariah-ekonomi/18/04/16/p798df374-penggunapaytren-tembus-2-juta (Irwan Kelana, 2018). 
Strategi yang dilakukan dalam aplikasi paytren ini juga cukup "canggih" dengan menggunakan aplikasi teknologi yang sedang berkembang pesat di masyarakat Indonesia saat ini ditambah dengan sosok seorang ustadz yang cukup populer dimana jumlah pengikutnya tidak sedikit dan sosok seorang ustadz sendiri merupakan salah satu panutan hidup khususnya dalam hal agama karena asumsi masyarakat bahwa seorang ustadz memiliki pengetahuan mengenai agama jauh lebih banyak daripada masyarakat pada umumnya sehingga hal ini cukup mudah bagi masyarakat untuk mempercayai setiap kegiatan yang dilakukan oleh Ustadz tersebut. Penggunaan nilai-nilai ajaran agama (khususnya dalam hal ini ajaran agama Islam) yang mengutamakan nilainilai keberkahan dan nilai-nilai agama lainnya menjadi semacam "pelengkap" dalam bisnis keuntungan yang diperoleh dalam setiap transaksi paytren ini.

\section{Komersialisasi Dakwah Dalam A plikasi Paytren}

Menurut Muzzaki (2009) dalam Wahidah (2015) komodifikasi agama Islam seperti yang terjadi di Indonesia, pada dasarnya merupakan sebuah proses komersialisasi. Dalam hal ini, ajaran-ajaran yang terkandung di dalam Islam, ide, ekspresi maupun simbol dapat ditransformasikan kepada masyarakat dalam sebuah bentuk nyata serta dapat menjadi produk yang dapat dikonsumsi ataupun diperjual belikan dalam upaya mendapatkan keuntungan. ${ }^{12}$ Lebih lanjut dijelaskan oleh Fealy dan Sally (2008) dalam Wahidah (2015) bahwa dengan adanya perkembangan teknologi, informasi, urbanisasi serta pertumbuhan ekonomi, merupakan faktor pendorong terjadinya komodifikasi agama, dimana individuindividu atau masyarakat menampilkan ekspresi keimanannya melalui berbagai macam komoditas yang menggunakan Iabel Islam. Sebagai contoh dalam kehidupan sehari-hari seperti menggunakan pakaian atau busana muslim, menabung di bank syariah, berlangganan SMS doa, melakukan perjalanan umroh dan kegiatan lainnya. ${ }^{13}$

Jika dihubungan dengan bisnis PayTren yang dijalankan oleh Ustadz Yusuf Mansur, dapat dikatakan bahwa bisnis PayTren tersebut merupakan salah satu bentuk komodifikasi (komersialisasi) agama. Hal tersebut dapat dilihat dari beberapa produk yang ditawarkan oleh PayTren merupakan komoditas yang menggunakan label Islam, seperti perjalanan haji dan umroh, sedekah dan investasi syariah. Salah satu

12 Wahidah, Faiqatun. 2015. K omodifikasi N ilai A gama dalam I klan Televisi (Studi A nalisis Semiotik Pada Iklan W ardah). Universitas I slam N egeri (UIN) Walisongo Semarang, Jurusan Komunikasi dan Penyiaran Islam. hlm. 39.

13 Ibid. hlm. 41 
fitur yang paling populer dalam aplikasi ini adalah fitur "sedekah" yang sangat kuat kaitannya dengan tagline ustadz Yusuf Mansur yang mengedepankan sedekah sebagai metode penyampaian dakwahnya.

\section{Sedekah Paytren}

Program sedekah ini merupakan salah satu produk yang dikeluarkan oleh perusahaan TRENI bagi mereka yang beragama Islam. Dalam program Sedekah ini sendiri terdapat beberapa jenis, yaitu (Soraya, 2017) ${ }^{14}$ :

a. Sedekah umum. Dalam Sedekah Umum ini, waktu untuk melakukan sedekah serta jumlah uang yang akan didonasikan oleh mitra PayTren, tidak ditentukan besarannya.

b. Sedekah $\mathrm{H}$ arian. M ekanisme yang ada di Sedekah Harian ini, memiliki sedikit perbedaan dengan Sedekah Umum, dimana dalam fitur ini memiliki tiga pilihan waktu dengan donasi yang ditetapkan sebesar Rp. 2.000 setiap waktunya, diantara pukul 05.30, 12.30 dan 17.30.

c. Sedekah Produktif. Sedangkan untuk sedekah produktif ini hanya dilakukan apabila terdapat rencana kegiatan produktif yang akan dilakukan oleh pihak PPPA Darul Quran. Jumlah donasi dan rentang waktunya tidak dibatasi dalam fitur Sedekah Produktif ini.

\section{Paytren : Transformasi Orientasi Praktek Keagamaan}

Paytren sebagai entitas bisnis komersial, melakukan komodifikasi agama dalam pengembangan bisnisnya. Dalam istilah lain Paytren dapat disebut sebagai produk keagamaan yang terdapat unsur komersialisasi di dalamnya, meliputi pemasaran dan transaksi. Paytren menjadi aplikasi bisnis yang sarat akan komersialisasi di dalam transaksinya. Tidak sebatas komersialisasi yang menjadi basis transaksi. Namun, jargon yang digunakan menunjukkan adanya komodifikasi agama. Jargon yang dimaksud seperti "Teman setia bayar-bayar yang mudah, hemat dan bermanfaat. M empermudah transaksi, memperkaya edukasi dan memperluas rezeki". ${ }^{15}$

Terminologi memperluas rezeki yang terdapat di dalam jargon atau moto Paytren bukan murni bisnis komersial umum (konvensional), melainkan ada diksi khusus "rezeki" yang menunjukkan komodifikasi agama. Sederhananya bisnis "dibalut" agama. Bisnis besutan ustadz Yusuf Mansur, semakin memperkuat entitas bisnisnya dengan resmi

14 Diakses dari https://www.republika.co.id/berita/dunia-islam/wakaf/17/04/16/0oi6mp319-ada-fitursedekah-di-paytren diakses pada 1 September 2018 (Dea Alvi Soraya, 2017).

15 Diakses dari https://www. paytren.co.id/ (diakses pada tanggal 28 Agustus 2018). 
meluncurkan uang elektronik paytren. Sejak didirikan 5 tahun yang lalu, jumlah penguna aplikasi PT Veritra Sentosa Internasional (Paytren) ini terus melonjak. Dalam kurun waktu terakhir, angkanya meningkat lebih 65 persen. Sebagai Founder sekaligus Komisaris Ustadz Yusuf Mansur menyebutkan bahwa Paytren memiliki visi menjadi perusahaan penyedia layanan teknologi perantara transaksi terbaik di tingkat nasional melalui pembentukan komunitas dengan konsep jejaring (seperti halnya MLM), dengan terus berupaya memberikan kemudahan kepada masyarakat untuk bertransaksi, dan berbuah rezeki. ${ }^{16}$

Selain terminologi agama "rezeki", -yang menunjukkan komodifikasi agama- yang digunakan dalam bisnis ini, diksi lain yang digunakan yaitu "sedekah". Sebab, seperti yang diketahui bahwa salah satu keunggulan dari paytren yaitu bagi para pengguna aplikasi otomatis bisa bersedekah. Lebih lanjut Hidayat (2017) menjelaskan secara tegas bahwa Paytren ini merupakan bisnis komersial dengan menggunakan bahasa agama, dan konstruksi otoritas yang dimiliki Ustadz Yusuf Mansur sebagai Pendakwah dalam waktu yang sama sebagai seorang pembisnis dengan status sebagai founder dan komisaris paytren. ${ }^{17}$

Bisnis yang berbasis pada aplikasi digital ini memang relevan dengan perkembangan teknologi kini. Sebab, Paytren menggunakan teknologi digital berbasis online. Selain itu otoritas yang dimiliki Ustadz Yusuf Mansur, misalnya, dengan media sosial yang dimilikinya akan memperluas pemasaran dari aplikasi ini, dengan menggunakan otoritasnya sebagai pendakwah. $\mathrm{H}$ al ini memperlihatkan bagaiman proses komodifikasi agama yang berlangsung dalam kasus Paytren Ustadz Y usuf Mansur. Bisnis yang digeluti Ustadz Yusuf Mansur ini menurut Budiandru, Dhiya 'Ulhaq, dan A rianurzahra (2018) seperti halnya bisnis MLM (Multi Level Marketing), dan kemudian disebutnya dengan “MLM Syariah". Namun, riset yang dilakukannya menunjukkan bahwa Paytren ini merupakan (dalam terminologi agama) transaksi (pertama) yang memiliki unsur Riba, yaitu Riba fadh'al. Selain itu, terdapatnya ketidakadilan di posisi mitra, dan terdapat unsur gharar (spekulasi) di dalam aktivitas transaksinya. ${ }^{18}$

Paytren memiliki kelebihan di dalam mengembangkan bisnisnya, sebab mengadopsi sistem epayment. Kelebihan yang dimilikinya, karena

16 Diakses dari https://www.republika.co.id/berita/ekonomi/syariahekonomi/18/04/16/p798df374pengguna-paytren-tembus-2-juta, diakses pada 2 September 2018.

17 Hidayat, Mansur, "Sedekah O nline Y usuf M ansur (Kajian tentang 0 toritas dan Bahasa A gama di M edia Sosial)". 2017, UIN Sunan Kalijaga.

18 Budiandru, Dhiya 'Ulhaq, dan Arianurzahra. 2018. “Multi Level Marketing in Sharia Accounting Perspective". A L-U RBA N : Jurnal Ekonomi Syariah dan Filantropi Islam. V ol. 2, N 0. 1, Juni 2018. 
persepsi kemudahan penggunaan (dengan sistem online) memiliki efek positif pada persepsi kegunaan (lebih mudah di dalam bertransaksi). ${ }^{19}$ Paytren dapat menarik para pelanggan, pertama karena memang menggunakan sistem e-payment. Sistem ini merupakan teknologi mutakhir di dalam transaksi dewasa ini. Kemudahan di dalam penggunaan transaksi dengan menggunakan aplikasi paytren ikut menjadi reasoning meningkatnya para pengguna entitas bisnis ini. Kedua, bisnis komersial dengan menggunakan bahasa agama (komodifikasi agama -dari fungsi utama agama) dan konstruksi otoritas Ustadz Yusuf Mansur sebagai pendakwah yang cukup populer tanah air, memperkuat dan mendukung entitas bisnis ini untuk terus berkembang dan diminati para penggunanya.

Paytren sebagai bentuk financial technology yang dikembangkan oleh ustadz Yusuf Mansyur hadir dalam masyarakat modern yang mengalami dependensia terhadap teknologi. Paytren merupakan salah satu contoh transformasi yang terjadi dalam sistem kapitalisme sekaligus praktek komersialisasi agama saat ini. Media dan status ustadz Yusuf Mansur sebagai salah satu ulama terkenal di Indonesia memiliki peran besar dalam perkembangan paytren hingga saat ini. Ustadz Yusuf Mansyur yang dikenal sebagai "ustadz sedekah" mampu mempengaruhi pemikiran masyarakat Indonesia akan manfaat sedekah. Pengaruh pemikiran ini tidak lepas dari peran media yang telah menjadi ustadz Yusuf Mansur sebagai ustadz selebritis dengan dakwahnya yang popular.

Berkembangnya paytren sebagai salah satu produk kapitalisme juga tidak terlepas dari konsumerisme yang menjamur di masyarakat Indonesia. Kepraktisan yang ditawarkan oleh paytren adalah nilai guna yang secara instan dapat dirasakan. Nilai guna ini diperkuat dengan jargon sedekah yang sudah dipopulerkan terlebih dahulu oleh ustadz yusuf mansyur di setap dakwahnya. Kombinasi kepraktisan sebagai nilai guna dan sedekah dengan nilai guna lainnya justru membawa paytren terjebak dalam praktek komodifikasi agama model baru. Model baru komodifikasi agama dalam paytren merupakan kombinasi komodifikasi agama yang dilakukan oleh pesantren dan pemilik modal dalam system kapitalisme sebelumnya.

Komodifikasi agama oleh pesantren lebih menitikberatkan pada nilai guna agama dibandingkan dengan nilai guna material yang tercipta dalam prosesnya. Komodimifikasi agama pemilik modal dalam sistem kapitalisme menjadikan nilai-nilai agama sebagai nilai tambah dalam strategi bisnis yang mampu meningkatkan keuntungan material bagi pemilik modal. Sedangkan komodifikasi agama yang dipraktekkan

19 Riskinanto, Kelana, dan Hilmawan. 2017. “The Moderation Effect of Age on Adopting EPayment Technology". Procedia Computer Science 124 (2017) 536-543. 
paytren sebagai bentuk reproduksi nilai kapitalisme yang dileburkan secara rata dengan nilai keagamaan (sedekah). Reproduksi nilai kapitalismeterkait konsumerismedidukung oleh perkembangan teknologi yang sudah diterima secara luas di masyarakat dikembangkan untuk melakukan bisnis kebutuhan ekonomi dasar masyarakat. Penggunaan nilai-nilai keagamaan sebagai Iandasan utama dalam paytren bertujuan untuk memanipulasi bisnis digital yang sulit diterapkan untuk kebutuhan dasar yang sifatnya mudah diperoleh dimanapun dan kapanpun tanpa bantuan teknologi.

\section{Paytren Sebagai Komoditas dan Gaya Hidup Masyarakat Konsumsi}

Berkembangnya metode pembayaran pada saat ini yang tidak lagi tergantung pada transaksi "tukar menukar" antara uang dan barang atau jasa menunjukkan bagaimana masyarakat telah mengalami perkembangan sebagai bentuk masuknya arus globalisasi dan modernisasi. Begitu pula hal nya dengan dakwah yang tidak lagi dilakukan secara konvensional melalui ceramah di tempat umum atau televisi melainkan dapat dilakukan melalui produk komersial yang menggunakan unsur teknologi dalam aplikasi di smartphone. Penggabungan da unsur utama antara ekonomi dan agama menjadikan perkembangan aplikasi paytren ini menjadi semacam komoditas berbasis agama dalam masyarakat modern saat ini.

Perkembangan masyarakat perkotaan saat ini terhadap aplikasi teknologi sangat pesat dan hampir semua kegiatan yang berhubungan dengan pembayaran dilakukan melalui uang elektronik salah satunya paytren tersebut. Kemudahan mekanisme pembayaran menjadi salah satu faktor pendorong masyarakat banyak menggunakan aplikasi uang elektronik. Menjadi suatu hal yang umum terjadi dalam perkembangan era globalisasi dan modernisasi ketika metode-metode klasik berubah dengan metode-metode baru yang menyesuaikan kebutuhan masyarakat saat ini yang mengacu pada kebutuhan pasar berbasis ekonomi digital. Era digital semakin membuat masyarakat khususnya wilayah perkotaan menginginkan kemudahan dalam setiap transaksi aktivitas mereka tanpa harus mengeluarkan usaha dan biaya yang besar.

Berjalan lurus dengan perkembangan ekonomi digital dalam hal transaksi ekonomi, perkembangan metode dakwah menjadi semakin mudah didapatkan hanya melalui aplikasi yang ada dalam perkembangan teknologi. Masyarakat dapat dengan mudah mengakses fiturfitur keagamaan melalui aplikasi yang terdapat dalam smartphone yang dimiliki oleh sebagian besar masyarakat wilayah perkotaan.

Untuk sebagian masyarakat era digital, memiliki smartphone atau gawai menjadi semacam kebutuhan dan gaya hidup melihat 
perkembangan teknologi yang pesat dan hamper menjangkau seluruh wilayah masyarakat. Menjadi hal yang kurang lazim ketika seseorang tidak memiliki perangkat tersebut. Ini merupakan salah satu kekurangan dalam aplikasi teknologi yang memuat unsur ekonomi dan agama dimana orang-orang yang tidak memiliki perangkat tersebut tidak dapat mengakses fitur-fitur teknologi yang memuat unsur ekonomi dan agama tersebut. A plikasi paytren ini secara tidak langsung menjangkau orangorang yang memiliki perangkat teknologi namun tidak dapat menjangkau orang-orang yang tidak memiliki perangkat teknologi tersebut. Karena itulah aplikasi ini lebih cenderung menjadi komoditas dan gaya hidup masyarakat era digital yang "melek" teknologi yang umumnya berada di wilayah perkotaan.

Masyarakat sebenarnya dapat dengan mudah memenuhi kebutuhan ekonomi dasar dimana pun dan kapanpun tanpa bantuan bisnis digital. Melihat kecenderungan tersebut, komodifikasi agama dalam bentuk nilai guna sedekah digunakan secara langsung oleh ustadz Yusuf Mansyur untuk memanipulasi tujuan ekonomi kapital isme dalam Paytren. Kondisi ini telah mengubah nilai-nilai keagamaan yang bersifat immaterial menjadi material secara implisit.

Keberadaan paytren dengan model dan sistemnya yang berbeda, telah menarik masyarakat Indonesia dengan nilai konsumerismenya untuk mensimplifikasi nilai guna dari sedekah. Dengan kata lain, nilai guna sedekah yang bersifat immaterial bertransformasi kepada imbali balik material secara instan. Komodifikasi agama dalam Paytren secara tidak langsung telah menunjukkan bahwa ritual keagamaan yang bersifat konservatif dengan imbali balik immaterial sudah tidak lagi istimewa di masyarakat Indonesia yang lebih mementingkan imbal balik material yang dapat dirasakan langsung melalui model bisnis yang diterapkan Paytren. Alasan utama pengguna paytren menggunakan alat pembayaran ini dalam transaksi ekonomi dalam kehidupan sehari-harinya mereka setidaknya mencakup 3 hal utama yaitu : memberikan kemudahan dalam bertransaksi tanpa perlu menggunakan usaha yang banyak; memberikan bisnis keuntungan dalam setiap transaksi yang berlangsung; dan memberikan pengetahuan dan nilai-nilai agama yang terkandung dalam aplikasi teknologi pembayaran paytren tersebut.

Kemudahan dalam melalukan transaksi dalam hal ini mengacu pada salah satu prinsip utama ekonomi yaitu mendapatkan hasil semaksimal mungkin dengan menggunakan usaha atau tenaga yang seminimal mungkin. Sebagai contoh misalnya jika seseorang tersebut ingin melakukan membeli pulsa yang sebelumnya biasa dilakukan di countercounter elektronik atau kios-kios pulsa dimana untuk dapat ke tempat tersebut diperlukan usaha dan tenaga seperti jalan kaki yang mengeluarkan tenaga dan keringat atau menggunakan kendaraan bermotor 
jika lokasi tempat membeli pulsa tersebut cukup jauh secara jarak sehingga muncul biaya untuk penggunaan motor tersebut termasuk bensin atau ongkos yang dikeluarkan. Dan kini dengan adanya aplikasi paytren tersebut, tidak perlu lagi mengeluarkan biaya ongkos dan tenaga untuk membeli pulsa. Cukup dengan transaksi melalui aplikasi paytren di smartphone atau gadget yang bisa dilakukan dimana saja dan kapan saja. Ditambah keuntungan yang didapat dimana nominal pembelian untuk pulsa tersebut lebih murah dibandingkan dengan kios-kios elektronik. Keuntungan yang dirasakan menjadi lebih bermanfaat bagi pengguna aplikasi paytren ini dibandingkan dengan usaha yang dilakukan sebelumnya sehingga membuat mereka kini beralih ke aplikasi paytren ini. Hal ini juga berlaku untuk pembayaran Iainnya semisal: pembayaran tagihan listrik atau telepon yang biasanya dilakukan di kantor pos, pembayaran tiket perjal anan kereta, pesawat dan beberapa transaksi lainnya yang berkaitan dengan kehidupan sehari-hari masyarakat pada umumnya.

Masih berkaitan dengan kemudahan metode pembayaran, sudah disebutkan sebelumnya mengenai kemudahan pembayaran yang sekaligus memberikan keuntungan. Keuntungan yang didapat selain biaya dan ongkos yang lebih murah, adalah dimana dalam transaksi ekonomi yang dilakukan melalui aplikasi paytren ini, penggunanya mendapatkan persentase keuntungan dari setiap transaksi yang dilakukan. Sebagai contoh dalam pembayaran tagihan listri atau pembelian pulsa dimana dari setiap transaksi tersebut, pengguna juga mendapatkan semacam persentase cashback yang jumlahnya variatif tergantung dari besarnya biaya transaksi yang dilakukan. Hal ini akan semakin besar ketika pengguna paytren tersebut juga memiliki "bawahan" atau orang yang bergabung dalam aplikasi paytren melal ui pengguna sebelumnya dimana transaksi yang dilakukan oleh pengguna yang ada dibawah pengguna sebelumnya akan memberikan keuntungan untuk pengguna diatas atau orang yang mengajaknya dan hal ini bersifat kumulatif, semakin banyak orang yang diajak bergabung dalam aplikasi paytren melalui dirinya sebagai agen, maka akan semakin besar keuntungan yang didapat orang yang mengajaknya tersebut. Dalam kalimat lain, leader akan mendapatkan akumulasi keuntungan dari setiap transaksi yang dilakukan oleh orang yang diajaknya.

Faktor ketiga adalah bagian yang paling menarik dimana dalam aplikasi yang memiliki nilai-nilai ekonomis dalam hal ini keuntungan, ternyata memiliki unsur lain yang bersifat profan yang berkaitan dengan nilai-nilai agama yang umumnya berfungsi dalam mengatur kehidupan manusia. Durkheim mengasumsikan agama sebagai suatu sistem kepercayaan yang terpadu dan praktek-praktek yang berhubungan dengan benda-benda suci, yakni benda-benda yang disendirikan dan 
terlarang-kepercayaan dan prakteknya yang menyatu ke dalam satu komunitas moral yang disebut jemaah atau umat. Agama memiliki peranan yang sangat penting dalam peningkatan integrasi sosial dalam masyarakat. Agama adalah cara masyarakat memperlihatkan dirinya sendiri dalam bentuk fakta sosial nonmaterial.

Dalam hal aplikasi paytren ini unsur nilai-nilai agama menjadi salah satu faktor yang cukup menonjol dalam suatu mekanisme pasar yang memiliki tujuan utama yaitu untuk mendapatkan keuntungan. Salah satunya dalam aplikasi paytren ini yaitu fitur Selamat M orning Indonesia dan fitur Sedekah. Dua fitur ini merupakan fitur-fitur yang menekankan pada nilai-nilai keagamaan dalam bisnis keuntungan. Fitur Selamat M orning Indonesia merupakan program buku digital dari Ustadz Yusuf Mansur dimana buku tersebut berisi tentang ajaran keberkahan di pagi hari. Lalu fitur Sedekah merupakan fitur dimana penggunanya dapat melakukan kegiatan sedekah secara praktis. Fitur-fitur keagamaan ini dalam aplikasi paytren merupakan unsur nilai-nilai keagamaan yang mengajarkan salah satu nilai keberkahan dimana tidak hanya keuntungan dunia yang didapat melainkan keuntungan akhirat yang memang secara kasat mata tidak dapat diukur nilainya melainkan diyakini oleh masing-masing individu.

Dalam bisnis keuntungan yang didapat melalui aplikasi paytren ini, unsur nilai-nilai agama menjadi semacam sarana "penghubung" antara kehidupan duniawi dan kehidupan akhirat. A tau dengan kata lain dalam wujud kegiatan atau transaksi, aplikasi paytren ini menjembatani antara kehidupan beragama dengan kehidupan ekonomi yang satu sama lain saling menopang dan saling menguatkan. Dalam ajaran keberkahan melalui fitur Selamat M orning Indonesia diajarkan bagaimana individu dalam berkegiatan sehari-hari khususnya kegiatan ekonomi akan lebih baik jika diawali dengan doa dan praktek ibadah lainnya yang menunjang secara spritualitas kegiatan yang dilakukan pada hari tersebut bisa berjalan dengan baik dan lancar sesuai dengan harapan. Lalu dalam fitur sedekah diajarkan bagaimana dalam setiap kegiatan ekonomi yang mendatangkan keuntungan akan semakin berkah (secara spiritualitas) jika sebagian keuntungan tersebut disisihkan atau disumbangkan kepada pihak lain yang berhak menerimanya yang biasa disebut sebagai sedekah. A plikasi paytren ini juga disebut memiliki salah satu tujuan keagamaan dimana dalam setiap keuntungan yang didapat akan disumbangkan untuk pembangunan masjid dan biaya keseharian anak-anak yatim dan kaum dhuafa yang tidak mampu. $\mathrm{Hal}$ ini merupakan tujuan yang bersifat akhirat dimana dalam hal ini mencari pahala (rewards) atau mendekatkan diri dengan Tuhan menjadi acuan utama dalam setiap kegiatan transaksi ekonomi yang dilakukan individu. 


\section{Penutup}

Dari beberapa penyataan diatas, dapat terlihat bagaimana agama menjadi unsur utama yang "mengawasi" sekaligus memberikan arah bagaimana transaksi ekonomi yang terpaku pada definisi mencari keuntungan bisa saling beririsan dengan kehidupan beragama yang menjadi panutan hidup seseorang dalam kehidupannya sekaligus saling menguatkan satu sama lain baik dalam kegiatan ekonomi maupun kegiatan keagamaan. $\mathrm{H}$ al inilah yang menjadi salah satu faktor pengguna paytren saat ini relatif cukup banyak khususnya dalam masyarakat perkotaan Indonesia saat ini dimana agama menjadi salah satu faktor penentu bagaiman seseorang menjalani kehidupannya. Agama menjadi fondasi utama sekaligus panutan hidup dalam kehidupan manusia yang menjunjung tinggi nilai-nilai moral dan etika yang dapat tercermin melalui kegiatan aktivitas atau perilaku kehidupannya sehari-hari. ${ }^{20}$

* Tri Djoko Pariworo

M ahasiswa Program M agister Jurusan Sosiologi, Fakultas IImu Sosial dan IImu Politik U niversitas Indonesia. Email : tri.pariworo@gmail.com

\section{BIBLIO G RAFI}

Jurnal

Budiandru, Dhiya “Ulhaq, dan Arianurzahra. 2018. “Multi Level Marketing in Sharia A ccounting Perspective". A L-U RBA N : Jurnal E konomi Syariah dan Filantropi Islam. Vol. 2, No. 1, Juni 2018.

Hidayat, Mansur. 2017. "Sedekah O nline Yusuf M ansur (Kajian tentang Otoritas dan Bahasa A gama di M edia Sosial)". UIN Sunan Kalijaga.

Geertz, Clifford. 1986. Islam O bserved: Religious Development in M arocco and Indonesia. N ew Heaven and London : YaleUniversity Press, chapter 1, "Two Countries, Two Cultures"

Riskinanto, Kelana, dan Hilmawan. 2017. "The Moderation Effect of Age on Adopting E-Payment Technology". Procedia Computer Science 124 (2017) 536-543.

Wahidah, Faiqatun. 2015. Komodifikasi Nilai A gama dalam Iklan Televisi (Studi A nalisis Semiotik Pada Iklan W ardah). Universitas Islam Negeri (UIN) Walisongo Semarang, Jurusan Komunikasi dan Penyiaran Islam.

20 Kahmad, Dadang. 2000. M etodeP en elitian A gama, Perspektif IImu Perbandingan A gama. Bandung: CV Pustaka Setia. HIm 24-25. 
Buku

Coutas, Penelope. 2008. Fame, Fortune, Fantasy : Indonesia Idol and The New Celebrity dalam Ariel Heriyanto (ed.), Popular Culture in Indonesia; Fluid Identities in Post-Authoritarian Politics. New York: Routledge

Fealy et.al (2012) U stadz Seleb, Bisnis M oral \& Fatwa O nline: Ragam E kspresi Keislaman Indonesia Kontemporer. Depok : Komunitas Bambu.

Kahmad, Dadang. 2000. M etode Penelitian A gama, Perspektif IImu Perbandingan A gama. Bandung : CV Pustaka Setia.

Mosco, Vincent. 2009. The Political Economy of Communication, $2^{\text {nd }}$ edition. Sage Publications.

Yuliharto, Freddy 1993. Gejolak Kapitalisme. Jakarta : Golden Terayon Press.

Publikasi Elektronik

https://old.treni.co.id/w p.../P rofil-P erusahaan-PT .-V eritra-SentosaInternasional (diakses tanggal 14 A gustus 2018)

https://www.paytren.co.id/ (diakses pada tanggal 28 Agustus 2018)

https://www.republika.co.id/berita/dunia-islam/wakaf/17/04/16/00i6mp319ada-fitur-sedekah-di-paytren diakses pada 1 September 2018 (Dea Alvi Soraya, 2017)

https://www.suara.com/bisnis/2017/10/21/114357/yusuf-mansur-dari-dakwahmerambah-dunia-bisnis diakses pada 2 September 2018 (Adhitya Himawan, 2017)

https://www.republika.co.id/berita/ekon omi/syariahekon omi/18/04/16/ p798df374-pengguna-paytren-tembus-2-juta, diakses pada 2 September 2018.

https://republika.co.id/berita/ekonomi/syariah-ekonomi/18/04/16/p798df374pengguna-paytren-tembus-2-juta diakses pada 2 September 2018. (Irwan Kelana, 2018). 